\title{
Dynamics and consequences of water level fluctuations of selected lakes in the catchment of the Ostrowo-Gopło Channel
}

\author{
Adam Piasecki, Włodzimierz Marszelewski \\ Department of Hydrology and Water Management, Nicolaus Copernicus University, Lwowska 1, 87-100 Toruń, Poland, \\ e-mail: piasecki@doktorant.umk.pl (corresponding author), marszel@umk.pl
}

\begin{abstract}
The article discusses water level fluctuations in lakes and the associated changes in the lake surface and water resources in the years 1992-2011. On the basis of detailed field studies carried out in the hydrological year 2011, short-term and dynamic changes in the lakes' hydrology were determined. Changes in hydrological lake types were evoked by unexpected hydro-meteorological situations, in particular high precipitation totals and sudden thaws in winter. The main symptom of the lake type change was the restoration, after nearly 10 years, of channels connecting the lakes. In addition, a strong interdependence was recorded in the difference between evaporation and precipitation, as well as the mean annual ranges of lake water levels in the years 1992-2010.
\end{abstract}

Key words: lakes, water resources, water level fluctuations, Gniezno Lakeland

\section{Introduction}

Water levels in lakes are constantly fluctuating, which is usually caused by natural processes. Recorded changes seen in different time scales are the result of temporary imbalances between inflow and outflow components of the water balance. Hydro-meteorological conditions and the elements of the natural environment, modified by anthropogenic influences, generate significant structural and functional transformation of the intrinsic properties of limnic ecosystems. Water level fluctuations may lead to temporary or permanent changes in physical and chemical properties of water, transformations of lake basins and changes in the species structure in a water body (Borowiak 2000).

Many authors have discussed water level changes in lakes, e.g. Skibniewski (1954), Pasławski (1972), Jańczak and Choiński (1993), Borowiak (2000). Climatic conditions are most often mentioned as a reason for short fluctuations in average annual water levels. Persistent, severe lowering or rising of a lake water level is usually related to draining and damming projects. The most commonly observed situations are those of indirect human impact on the formation of lake water resources. The best example is the reduction of forest cover in the catchment or the introduc- tion of crops with significant water needs. Both factors result in reduced water resources and increased evaporation in the catchment.

Analysing the impact of climatic conditions on the water level in lakes one can observe deviations from the average values, especially in wet and dry years. At the same time it should be noted that in certain lakes water levels in wet and dry years have different ranges, which are often shifted in time (Jańczak and Choiński 1993).

A review of the literature suggests that seasonal fluctuations in water levels in postglacial lakes on the European Lowland are small and not very meaningful in the long run (Pasłwaski 1972; Borowiak 2000). The following analysis of water levels of lakes in the catchment of the Ostrowo-Gopło Canal indicates that this kind of statement is not always correct.

\section{Study area}

The study area is located in the north-eastern part of the Greater Poland-Kuyavian Lakeland, specifically in the area of the Gniezno Lakeland (Fig.1). The northern border of the area is the valley of the River Welna; the western one, the valley of the River Warta; the eastern one, Lake Gopło and the valley of 


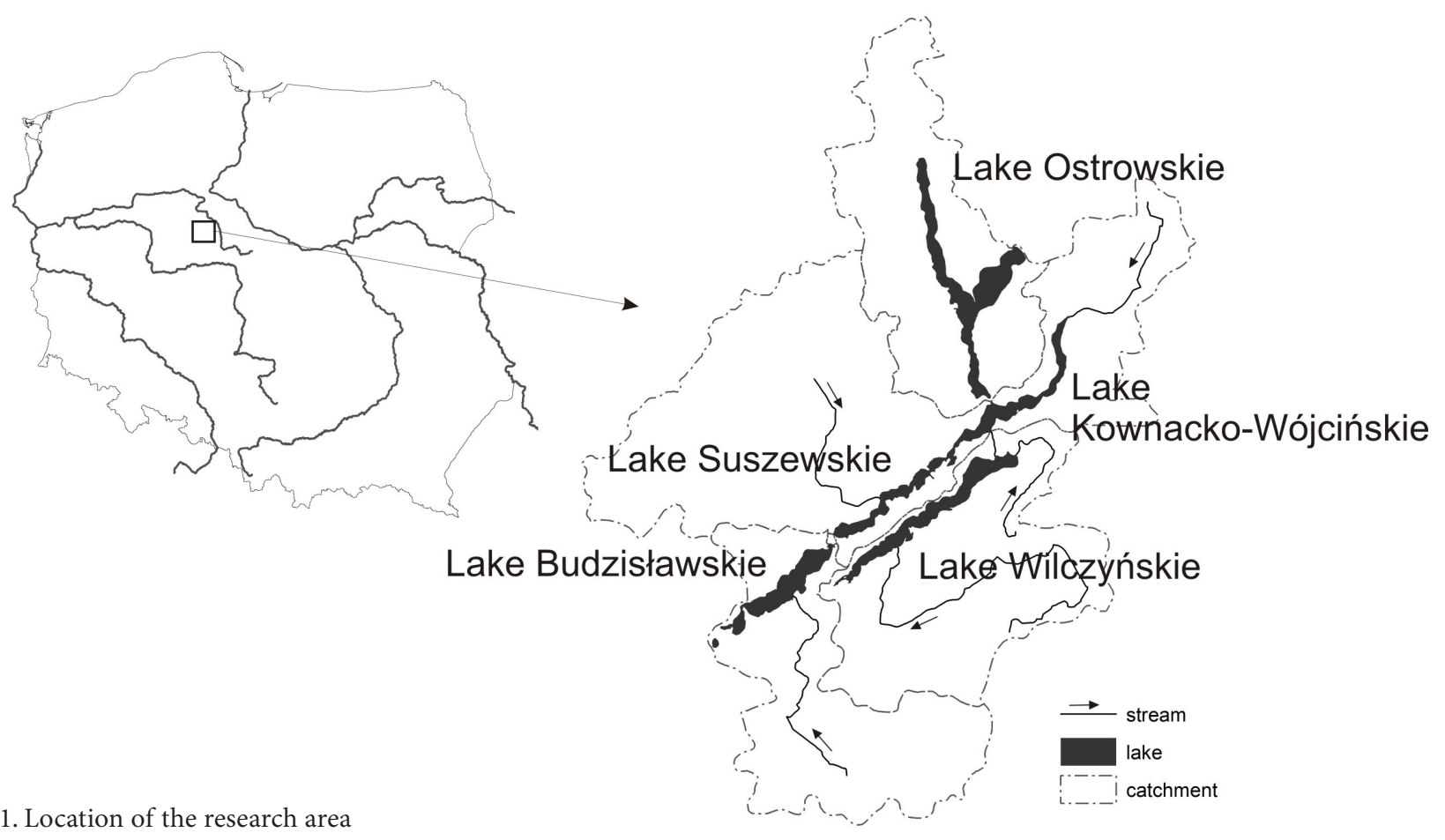

Fig. 1. Location of the research area

the River Noteć; and the southern one, the Września Plain. The surface area of the region is about $4300 \mathrm{~km}^{2}$ and corresponds to the landforms mainly associated with the Poznan Phase of the Weichselian (Vistulian) Glaciation. The area of the Gniezno Lakeland is dominated by glacial till and brown earth soils. Due to favourable natural conditions this is a well-developed agricultural region. There are a few forested patches on outwash sands (Kondracki 2011).

The Greater Poland-Kuyavian Lakeland has a very low mean precipitation. Slightly higher rainfall is recorded in its northern regions. The lowest precipitation totals are recorded in the catchments of the Rivers Wełna and Mogilnica and of the Mosiński Canal. The weather station closest to the study area, Kleczewo, records $528 \mathrm{~mm}$ of average (1992-2011) annual precipitation. This value is adjusted, taking into account the inevitable measurement errors (and therefore it is increased by $15 \%$ compared to the measured values). What should also be noted is the high precipitation variability in this part of Poland. In some years the (adjusted) precipitation is only slightly over $400 \mathrm{~mm}$ (e.g., in 2003 it was only $407 \mathrm{~mm}$ ). Total annual precipitation rarely exceeds $600 \mathrm{~mm}$. From the year 2000 a downward trend is observed in total precipitation (except for 2010, Fig. 2).

With the decreasing annual precipitation a clear upward trend in the size of evaporation is observed.
This is explained by the increase in such meteorological elements as wind velocity, air temperature, relative insolation and saturation deficit (Table 1). Hence the total annual evaporation from the free surface of water over the last 10 years has been over $800 \mathrm{~mm}$ (Fig. $3)$.

Hydrographic conditions in the discussed area have been largely transformed by human activity. Already in the seventeenth century, during so-called Dutch (or Olender) colonisation, reclamation works and regulation of rivers in the wet areas of the valleys of the Rivers Noteć and Obra were undertaken. The aim of this work was mostly to drain the land most suitable for agriculture. As a result, many riverbeds were straightened and no-through lakes were included in the drainage system (Marszelewski et al. 2011). Moreover, many draining ditches were linked to the existing watercourses, which changed the density and layout of the hydrographic network. Large drained areas were now over-dry, some of the permanent watercourses became intermittent and the water level of many lakes decreased by up to $1.4 \mathrm{~m}$ (Kaniecki 1997).

The surface areas of the studied lakes were significantly reduced during the second half of the twentieth century. At the beginning of the twenty-first century, the lakes covered an area from 86 to 262 ha (Table 2). 


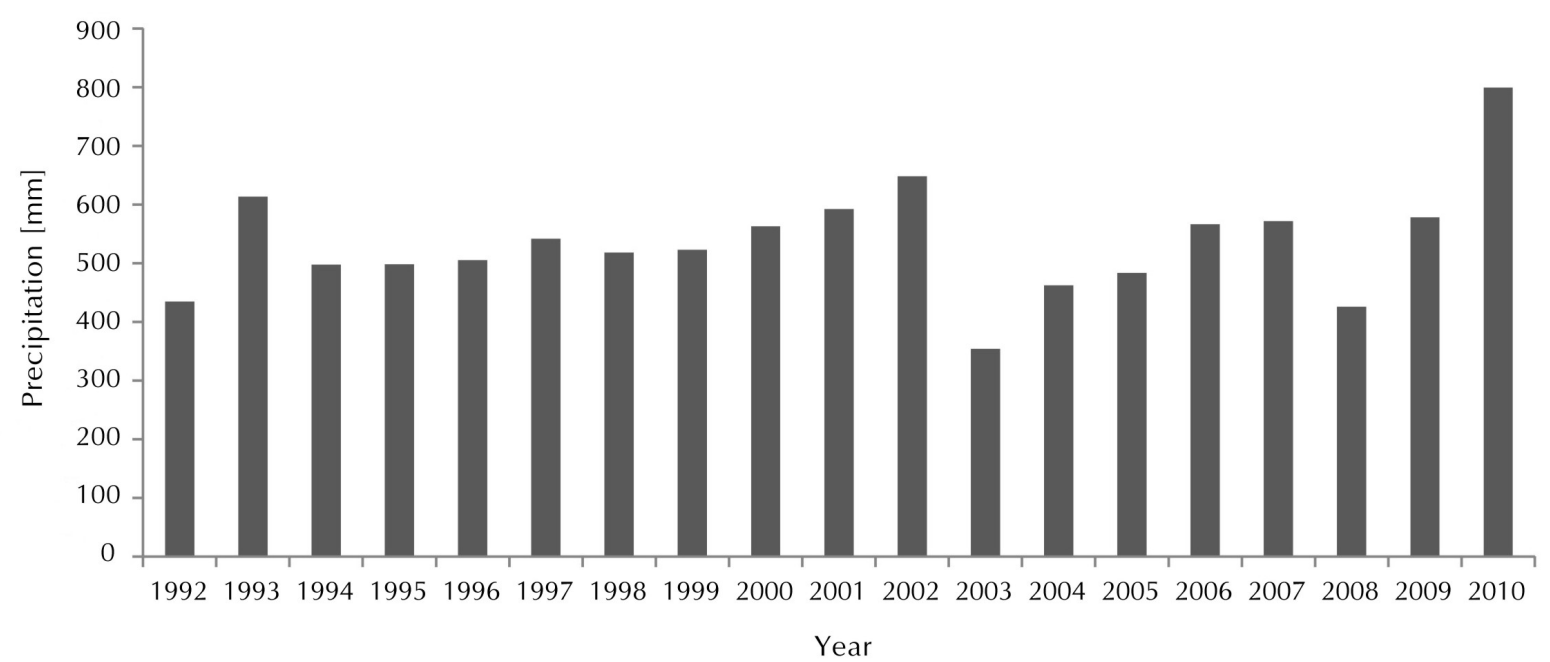

Fig. 2. Total precipitation at the Kleczew weather station: 1992-2010

Table 1. Mean annual values of the selected meteorological elements from Powidz: 2002-2011 (calculated from the data obtained from the military airport in Powidz)

\begin{tabular}{|c|c|c|c|c|c|}
\hline \multirow{2}{*}{ Year } & Air temperature & Water vapour pressure & Relative humidity & Deficit of water vapour pressure & Wind speed \\
\hline & {$\left[{ }^{\circ} \mathrm{C}\right]$} & {$[\mathrm{hPa}]$} & [\%] & {$[\mathrm{hPa}]$} & {$\left[\mathrm{m} \mathrm{s}^{-1}\right]$} \\
\hline 2002 & 9.21 & 8.88 & 76.31 & 2.75 & 3.65 \\
\hline 2003 & 8.75 & 8.43 & 74.76 & 2.85 & 3.33 \\
\hline 2004 & 8.8 & 8.65 & 76.4 & 2.67 & 3.5 \\
\hline 2005 & 8.71 & 8.48 & 75.36 & 2.77 & 3.37 \\
\hline 2006 & 9.2 & 8.76 & 75.37 & 2.87 & 3.47 \\
\hline 2007 & 9.7 & 9.31 & 77.4 & 2.72 & 4.17 \\
\hline 2008 & 9.78 & 8.84 & 73.18 & 3.25 & 4.01 \\
\hline 2009 & 8.9 & 8.89 & 78 & 2.51 & 3.67 \\
\hline 2010 & 7.7 & 8.24 & 78.43 & 2.26 & 3.82 \\
\hline 2011 & 9.28 & 9.6 & 75.44 & 3.62 & 3.98 \\
\hline
\end{tabular}

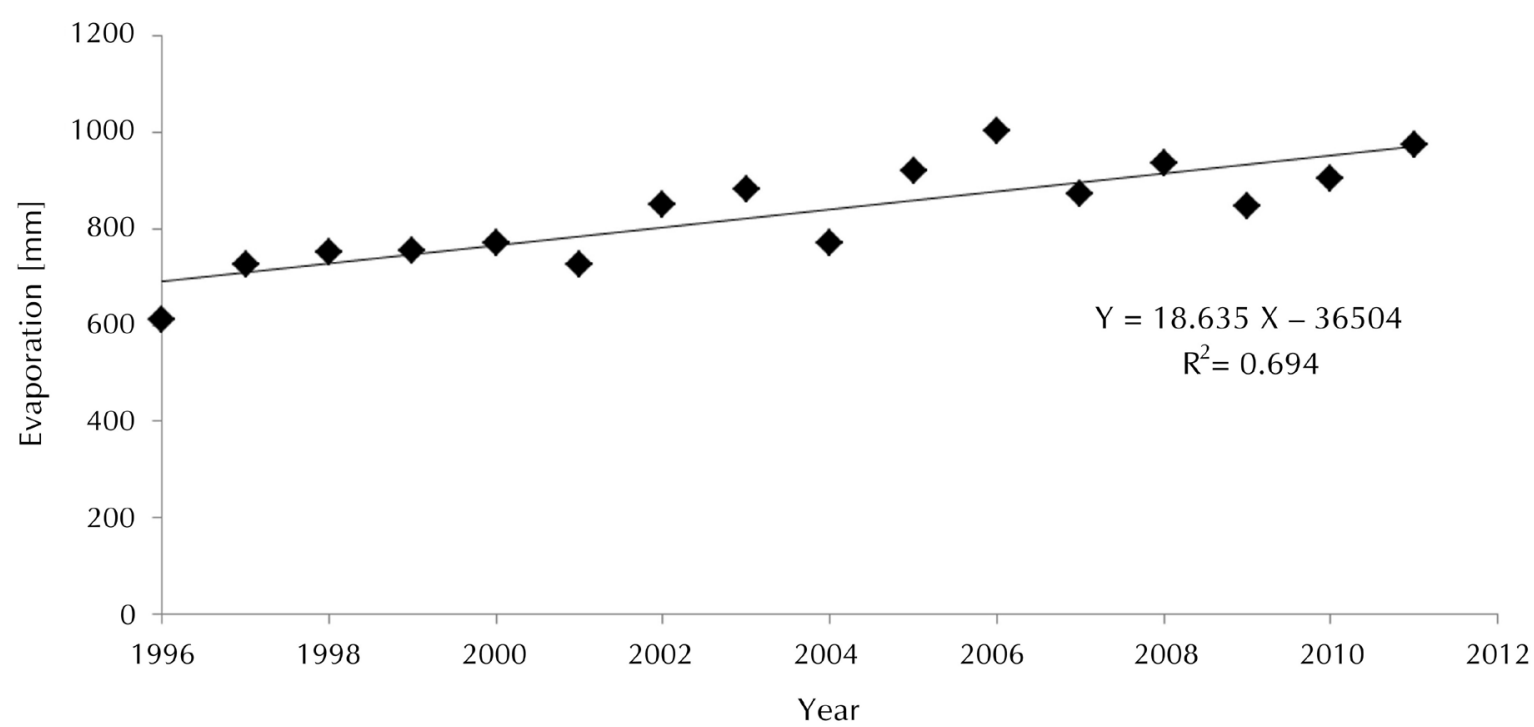

Fig. 3. Annual evaporation from the water surface in the south-western part of the Kuyavian Lakeland: 1996-2012 (after Kędziora 2011, supplemented) 


\section{Methods}

The aim of this study is to document the impact of short-term dynamics of changes in lake water levels on water resources. The lakes were monitored in terms of their water levels and flow in watercourses. In the lakes HOBO U20 loggers were installed, which automatically measured water levels (typical error \pm 1.5 $\mathrm{cm}$ ). The paper also includes the results of the measurement of lake water levels conducted by the Konin Coal Mine. The analysis covered hydrological years (from November to October).

On the basis of cartographic materials at the scales of 1:10 000 and 1:25 000 as well as the bathymetry of the lakes, satellite images and GIS software, a numerical model of the catchment of the lakes was developed. The main objective of the creation of the digital terrain model was to use it for a number of calculations necessary to assess the changes in water resources. The digital terrain model also enabled a more accurate spatial recognition of problems associated with water management in the area.

In the literature, two hypotheses are given regarding the reasons for changes in water levels in the studied lakes. One of them concerns the impact of the cone of depression related to the operation of the lignite opencast mine in Konin. The second hypothesis points to the influence of climatic factors, particularly related to climate change and the negative trends in total annual precipitation (Kędziora 2011). In this paper, focusing on the second hypothesis, the authors analysed the most significant components of the climate of the area. This in particular considers precipitation and evaporation, which are critical for the vertical water exchange in lakes (VWE). Annual VWE values were compared with ranges in lake water levels in a given year (RLWL). Similarly, such calculations were conducted for the VWE and the difference between the average lake water level (ALWL) in the year $n+1$ and the year $n$.

\section{Results and discussion}

As already mentioned, a digital terrain model was developed for the studied lakes. Thanks to it, a series of data was obtained for such elements as changes in the surface area and capacity of lakes at the corresponding positions of the water level ( $\mathrm{m}$ above sea level). The results clearly show a very great dynamic of changes in both the surface area and the water volume in the lakes. The results obtained for Lakes KownackoWójcińskie and Suszewskie are presented in Figs 4 and 5. The dashed line shows the elevation of the water table at which the outflow of water from the lakes takes place. The consequence of this is the change in the hydrological types of lakes (outflow lake, flow-through lake, no-through lake).

In the winter season of 2011 the water volume of the analysed lakes unexpectedly increased to the value recorded in the 1960s. This half-year was characterised by the highest dynamics of changes in the surface area, water volume and water table level. This was due to the occurrence of unusual hydrometeorological situations, including in particular high precipitation totals. In November 2010, precipitation (140 $\mathrm{mm}$ ) exceeded four times the average for that month (Fig. 6). It represented about $30 \%$ of the average annual total precipitation for the area. Precipitation totals recorded in the previous months (e.g. $123 \mathrm{~mm}$ in July, $116 \mathrm{~mm}$ in August) were also significantly higher than the long-term mean for the area. This high precipitation (in summer) and low evaporation in the winter months resulted in an increase in the water levels of the surveyed lakes, unprecedented in recent years. As a result, the flow between the lakes was re-established for some time (it ceased to function in 2003).

Table 2. Basic morphometric data on lakes (based on the data of the Inland Fisheries Institute (IRŚ) in Olsztyn and own calculations)

\begin{tabular}{|c|c|c|c|c|c|c|}
\hline \multirow{3}{*}{ Lake } & \multicolumn{2}{|c|}{ Surface area } & \multicolumn{2}{|c|}{ Volume of the lake } & \multicolumn{2}{|c|}{ Depth by IRŚ } \\
\hline & $\begin{array}{c}\text { After IRŚ } \\
(1960 s)\end{array}$ & $\begin{array}{c}\text { Mean } \\
(1992-2010)\end{array}$ & $\begin{array}{c}\text { After IRŚ } \\
(1960 s)\end{array}$ & $\begin{array}{c}\text { Mean } \\
(1992-2010)\end{array}$ & Maximum & Mean \\
\hline & \multicolumn{2}{|c|}{ [ha] } & \multicolumn{2}{|c|}{$\left[\mathrm{dam}^{3}\right]$} & \multicolumn{2}{|c|}{$[\mathrm{m}]$} \\
\hline Ostrowskie & 314.5 & 262.1 & 31242.9 & 26496.2 & 35.1 & 9.9 \\
\hline Suszewskie & 91.6 & 86.2 & 7127.9 & 6337.1 & 25.0 & 7.8 \\
\hline Kownacko-Wójcińskie & 160.4 & 135.4 & 9218.6 & 7608.0 & 22.7 & 5.7 \\
\hline Budzisławskie & 155.9 & 146.1 & 17287.0 & 16351.9 & 36.7 & 11.1 \\
\hline Wilczyńskie & 189.5 & 177.7 & 14735.2 & 13914.7 & 24.9 & 7.8 \\
\hline
\end{tabular}




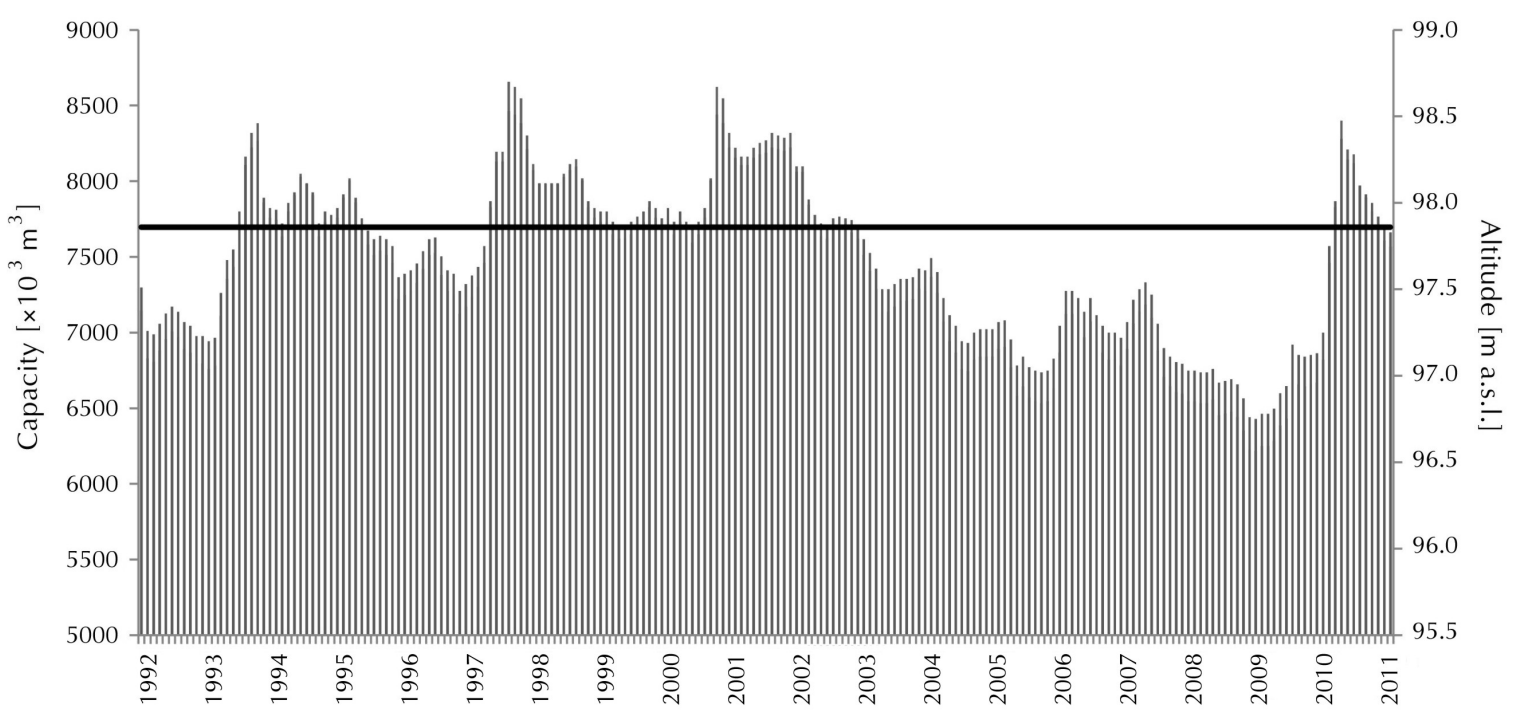

Fig. 4. Capacity changes of Lake Kownacko-Wójcińskie: 1992-2011

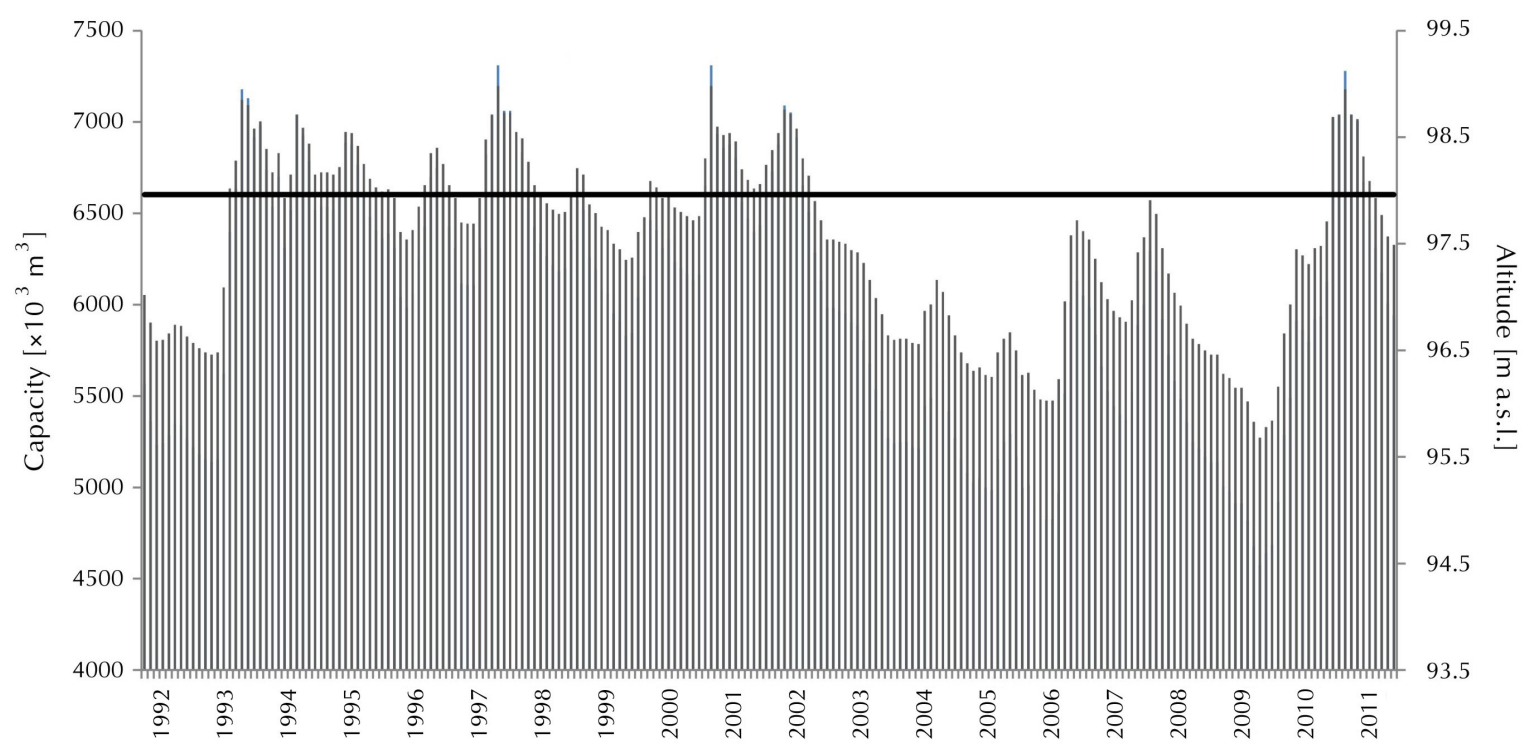

Fig. 5. Capacity changes of Lake Suszewskie: 1992-2011

Fig. 6. Percentage deviations in precipitation in some months of 2010 (based on the NOAA data from the website $<$ twojapogoda.pl $>$ ). Explanation: 1 - November 2010, 2 - December 2010
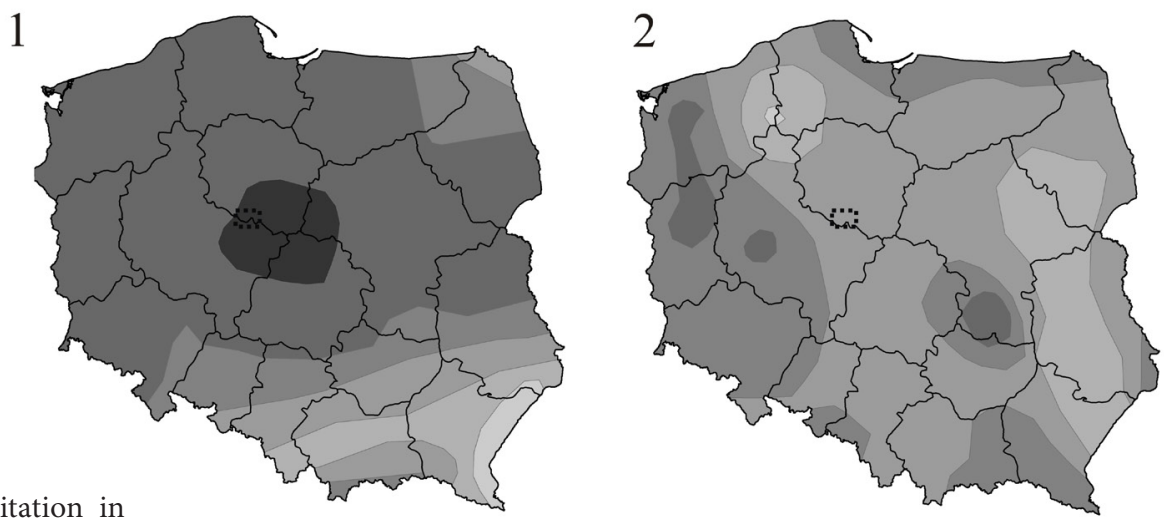

$\begin{array}{lllllll}400 & 200 & 150 & 125 & 100 & 75 & 50 \%\end{array}$ research area 
In January 2011 the maximum amount of water inflow to Lake Ostrowskie (lowermost) was $0.88 \mathrm{~m}^{3}$ $\mathrm{s}^{-1}$, which corresponds to the unit outflow of $14.71 \mathrm{~s}^{-1}$ $\mathrm{km}^{-2}$. At the same time, the maximum inflow to Lake Kownacko-Wójcińskie amounted to $0.98 \mathrm{~m}^{3} \mathrm{~s}^{-1}(25.6$ $1 \mathrm{~s}^{-1} \mathrm{~km}^{-2}$ ). As a result, $2970000 \mathrm{~m}^{3}$ of water shifted from Lake Suszewskie to Lake Kownacko-Wójcińskie, and $2910000 \mathrm{~m}^{3}$ from Lake Kownacko-Wójcińskie to Lake Ostrowskie. It follows that the water supplied to the lowest positioned Lake Ostrowskie was slightly reduced compared to Lake Kownacko-Wójcińskie situated higher up. This was due to the need to fill Lake Kownacko-Wójcińskie up to the water level which would allow the outflow to Lake Ostrowskie.

The analysed hydro-meteorological situations of the winter-season (November-April) of 2011 resulted in significant changes in the lake water resources. In April 2011, compared to November 2010, the volume of the lakes was larger, from $2.6 \%$ in the case of Lake Budzisławskie to $26.7 \%$ in the case of Lake Wilczyńskie (Table 3). In April 2011, the volume of the lakes was similar to the values of the 1960s, as calculated by the IRS in Olsztyn. A significant difference (of approx. 10\%) was found only in the case of Lake Ostrowskie.

As already mentioned, until 2002 the tested lakes were flow-through lakes. Since 2003, due to the discussed hydro-meteorological changes, these lakes have changed their hydrological type to no-through lakes. In the winter half-year of 2011, due to rising water levels and, one by one, the restoration of throughflows and tributaries, the lakes rapidly changed their hydrological types. The subsequent changes are presented in Fig. 7, which shows the dynamic change in the relationship between the lakes.

Thanks to the verification of the hypothesis of a significant impact of climate on the formation of water levels in the surveyed lakes, a number of data was obtained which, in some cases, indicate the existence of such a relationship. As evidenced by the calculations, there was no statistically significant correlation between the VWE and RLWL. Such a dependence of the 0.01 significance level was found for the VWE in a given year and the difference between the ALWL in the year $n+1$ and the year $n$ (Table 4 ). This relationship results from the delayed response of lakes to changes in meteorological conditions. For this reason, high precipitation and low evaporation in a given year result in an increase in water level in the lakes the following year.

The highest correlations were obtained for Lakes Ostrowskie and Kownacko-Wójcińskie, while the lowest for Lake Budzisławskie (Table 4). In addition, a strong dependence was found between the size of the catchment and the correlation coefficient. The larger the catchment area, the greater the correlation between the average annual ranges of the water levels in the lakes, and the difference between precipitation and evaporation.

It should be noted that anthropogenic factors also affect the studied lakes, as indicated by the coefficients of determination (in this analysis, of regression and correlation). They indicate that about $60 \%$ of the change in water levels can be explained by variability

Table 4. Relationship between the difference of evaporation and precipitation $(\mathrm{x})$ and the average annual water levels in the period 1992-2010

\begin{tabular}{llc}
\hline \multicolumn{1}{c}{ Lake } & Regression equation & $\begin{array}{c}\text { Correlation } \\
\text { coefficient }\end{array}$ \\
\hline Ostrowskie & $\mathrm{y}=0.3228 \mathrm{x}+17.483$ & 0.80 \\
\hline Kownacko-Wójcińskie & $\mathrm{y}=0.2823 \mathrm{x}+15.311$ & 0.78 \\
\hline Suszewskie & $\mathrm{y}=0.4844 \mathrm{x}+24.986$ & 0.74 \\
\hline Budzisławskie & $\mathrm{y}=0.1044 \mathrm{x}+0.0438$ & 0.64 \\
\hline Wilczyńskie & $\mathrm{y}=0.4055 \mathrm{x}+16.425$ & 0.74 \\
\hline
\end{tabular}

Table 3. Changes in lake water resources in the winter half-year of 2011

\begin{tabular}{|c|c|c|c|c|c|c|}
\hline \multirow{3}{*}{ Lake } & \multicolumn{3}{|c|}{ Volume of the lake } & \multirow{2}{*}{$\begin{array}{l}\text { Retention increase in } \\
\text { the winter half-year of } \\
2011\end{array}$} & \multicolumn{2}{|c|}{ Volume change in April 2011} \\
\hline & $\begin{array}{c}\text { 1960s } \\
\text { (after IRŚ) }\end{array}$ & $\begin{array}{c}\text { November } \\
2010\end{array}$ & $\begin{array}{l}\text { April } \\
2011\end{array}$ & & $\begin{array}{c}\text { Relative to the } \\
\text { 1960s }\end{array}$ & $\begin{array}{c}\text { Relative to } \\
\text { November } 2010\end{array}$ \\
\hline & \multicolumn{3}{|c|}{$\left[\mathrm{dam}^{3}\right]$} & {$\left[\mathrm{dam}^{3}\right]$} & \multicolumn{2}{|c|}{ [\%] } \\
\hline Ostrowskie & 31242.9 & 23620.4 & 27805 & 4184.6 & 13.4 & 17.7 \\
\hline Kownacko-Wójcińskie & 9218.6 & 6820.3 & 8178.3 & 1358.0 & 14.7 & 19.9 \\
\hline Suszewskie & 7127.9 & 6124.9 & 7002.9 & 878.0 & 12.3 & 14.3 \\
\hline Budzisławskie & 17287.0 & 15160.4 & 15559.3 & 398.9 & 2.3 & 2.6 \\
\hline Wilczyńskie & 14735.2 & 11000.0 & 13932.5 & 2932.5 & 19.9 & 26.7 \\
\hline
\end{tabular}




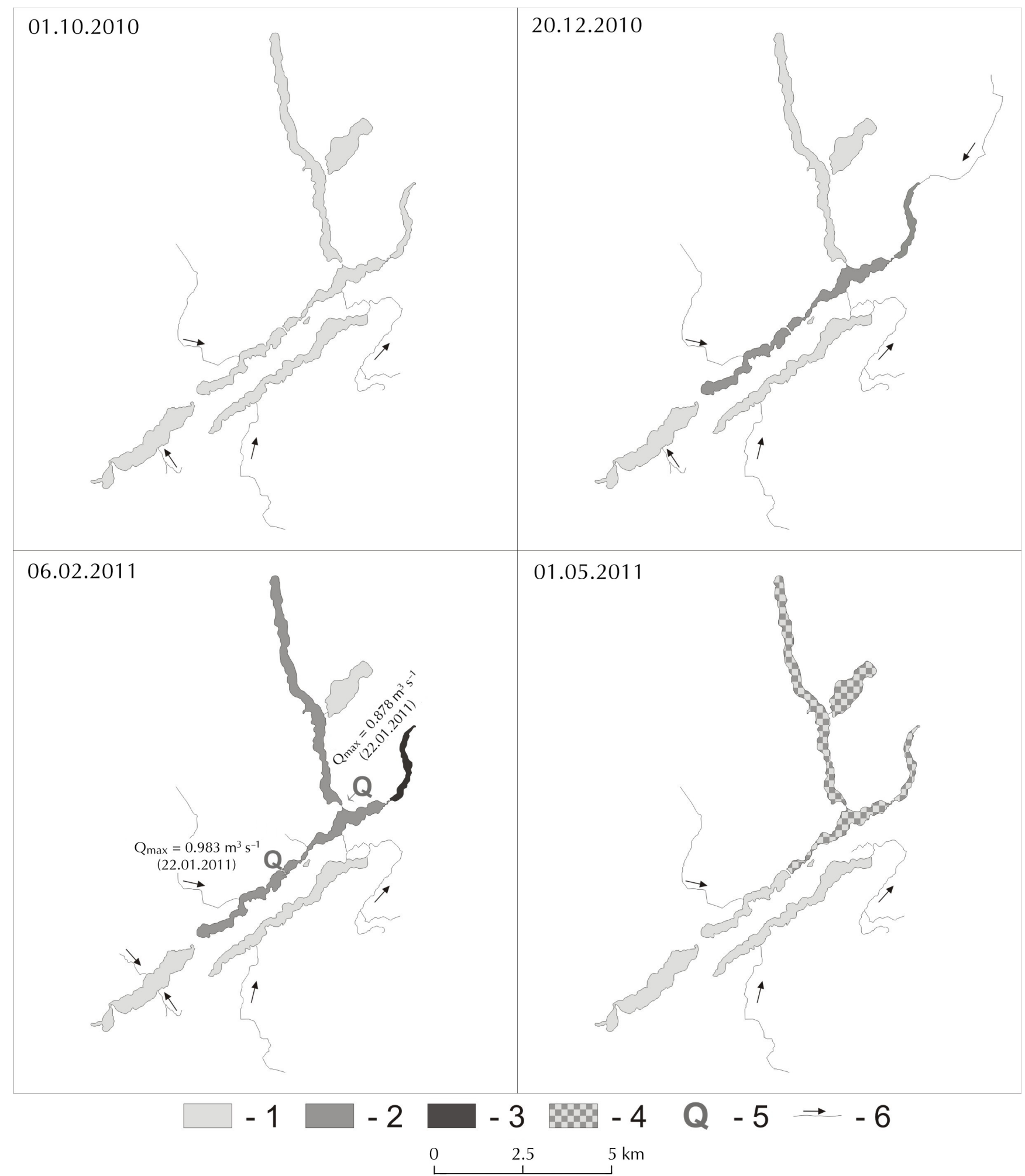

Fig. 7. Changes in hydrological types of lakes from October 2010 to May 2011. Explanation: 1 - outflow lake, 2 - flow-through lake, 3 no-through lake, 4 - lake with a variable flow direction, 5 - flow measurement point, 6 - stream 
in precipitation and evaporation. Therefore it can be concluded that there is a significant influence of other factors, particularly anthropogenic ones.

\section{Conclusion}

The research carried out by other authors (e.g. Dorożyński and Skowron 2002; Kunz et al. 2010; Ptak 2010) for the Greater Poland-Kuyavian Lakeland showed a significant reduction in the surface of lakes in the area. The problem of fluctuations in water levels in the lakes had been discussed - until recently - only in general terms. This study identified the importance of changes in water levels, which cause very serious consequences, including the hydrological types of lakes. These consequences result from the modification of the relationship between the lakes. In addition, the paper highlighted the fact that in previous years there were several changes in the relationship between the studied lakes. It should be noted that such an arrangement of lakes (and their interaction) is rarely found in nature, as they require appropriate conditions, both in terms of relief and weather conditions.

It should also be noted that in other studies, for instance of the ecological status or water quality, lakes are uniquely qualified to one of the existing hydrological types. However, it turns out that some of them (of significant surface areas in relation to the territory of Poland) may undergo short-term changes in their hydrological types, which is important for many reasons. Natural cyclical changes in hydrological types of lakes allow changes evoked by a sudden influx of significant amounts of water to be tracked. Such inflows are also important in terms of internal water circulation and, consequently, lead to changes in its physical and chemical properties.

The study also showed a significant correlation between the VEP in a given year and the difference in the ALWL in year $n+1$ and the year $n$. This correlation is justified by a delayed reaction of lakes to changes in meteorological conditions. As a result, high precipitation and low evaporation in a given year will result in an increase in water level in the following year. Additionally, a significant influence of the human impact on the water conditions in the area was stressed.

Hydrological implications, as well as economic, social and, above all, environmental, are the main reasons why monitoring of the studied lakes will be continued in the coming years.

\section{References}

Borowiak D., 2000, Reżimy wodne i funkcje hydrologiczne jezior Niżu Polskiego (Water regimes and hydrological functions of Polish Lowland lakes), Bad. Limnol. 2, Wyd. KLUG, Gdańsk, p.164 (in Polish, English summary).

Dorożyński R., Skowron R., 2002, Changes of the basin of Lake Gopło caused by melioration work in the $18^{\text {th }}$ and $19^{\text {th }}$ centuries, Limnol. Rev. 2: 93-102.

Jańczak J., Choiński A., 1988, Wahania poziomów wody jezior $\mathrm{w}$ latach 1956-1985 (Fluctuations in water levels of lakes in the years 1956-1985) [in:] Churski Z. (ed.) Naturalne i antropogeniczne przemiany jezior i mokradeł w Polsce (Natural and anthropogenic transformations of lakes and wetlands in Poland), Wyd. UMK, Toruń: 79-87 (in Polish).

Kaniecki A., 1997, Wpływ XIX-wiecznych melioracji na zmiany poziomu wód (Influence of 19th century reclamations on the changes in water level), [in:] Choiński A. (ed.) Wpływ antropopresji na jeziora, Wyd. UAM, Poznań-Bydgoszcz, 67-71 (in Polish).

Kędziora A., 2011, Warunki klimatyczne i bilans wodny Pojezierza Kujawskiego (Climatic conditions and water balance of the Kujawy Lakeland), Rocz. Glebozn. 62(2): 189203 (in Polish, English summary).

Kondracki J., 2011, Geografia regionalna Polski (Regional geography of Poland), Wyd. PWN, W-wa, pp. 441 (in Polish).

Kunz M., Skowron R., Skowroński S., 2010, Morphometry changes of Lake Ostrowskie (the Gniezno Lakeland) on the basis of cartographic, remote sensing and geodetic surveying, Limnol. Rev. 10: 77-85.

Marszelewski W., Ptak M., Skowron R., 2011, Antropogeniczne i naturalne uwarunkowania zaniku jezior na pojezierzu Wielkopolsko-Kujawskim (Anthropogenic and natural conditionings of disappearing lakes in the Wielkopolska-Kujawy lake district), Rocz. Glebozn. 62(2): 283-294 (in Polish, English summary).

Pasławski Z., 1972, Wieloletnie wahania i tendencje zmian poziomu wody jezior odpływowych w Polsce Północnej (Multiannual oscillations and trends towards the changes of the water level of outflowing lakes in Northern Poland), Prz. Geofiz. 17(3-4): 249-259 (in Polish, English summary).

Ptak M., 2010, Zmiany powierzchni jezior na tle zmian lesistości w środkowym i dolnym dorzeczu Warty od końca XIX wieku (Percentage of the area covered by forest and change in the surface of lakes in the middle and lower Warta River Basin from the end of the 19th century), [in:] Ciupa T., Suligowski R. (eds), Woda w badaniach geograficznych, Wyd. Uniwersytet Humanistyczno-Przyrodniczy Jana Kochanowskiego, Kielce: 151-159 (in Polish, English summary).

Skibniewski L., 1954, Wahania poziomów zwierciadła wody większych jezior pojezierzy: Pomorskiego i Mazurskiego (Fluctuations in water table levels of larger lakes of the Lakelands: Pomeranian and Masurian), Prz. Met. Hydr. 7(3-4): 159-172 (in Polish). 